\title{
Membrane-Spanning 4-Domains Subfamily A Member 7
}

National Cancer Institute

\section{Source}

National Cancer Institute. Membrane-Spanning 4-Domains Subfamily A Member 7. NCI

Thesaurus. Code C158457.

Membrane-spanning 4-domains subfamily A member 7 (240 aa, $\sim 26 \mathrm{kDa}$ ) is encoded by the human MS4A7 gene. This protein may play a role in signal transduction as part of a multimeric receptor complex. 